Sylwia Błaszczyk-Kowalska, Ph.D.

Laboratory of Special Education

Faculty of Educational Sciences

University of Lodz, 91-433 Łódź, Smugowa 10/12

Poland

\title{
AN EARLY SUPPORT OF DEVELOPMENT - BETWEEN THE THEORY AND PRACTICE
}

\section{Introduction}

The early support of development determined as institutionalized diagnostic and rehabilitation activity does not have too long tradition in Poland. As it is emphasized by Cieszyńska, Korendo (2008), for many decades the misconception was lingering in Poland that making a definitive diagnosis, and as we know this process often takes many years in Poland, should be the starting point of therapeutic activities. Currently, interdisciplinary research results confirm the need to undertake the intervention activities in the first months of life (Show, 2002; Serafin, 2005; Piszczek, 2007; Błaszczyk, Kałużna-Czaplińska, 2012).

The progress of modern medicine involves the possibility to rescue the children who previously had no chance to survive. It should be emphasized that those children have to be surrounded by possibly early, specialist care, and the objective of the undertaken intervention is to prevent the irreversibility of irregularities occurring in the development or to mitigate the results of irregularities that already occurred. (Cytowska, 2008).

\section{Determination of the Early Development Support}

For A. Twardowski, the essence of early development support is the provision of professional, comprehensive and multidisciplinary medical, psychological and pedagogical assistance. Early assistance should be comprehensive and it should be given both to the disabled children and the members of their families. Early assistance seeks to optimize the functioning of the whole family system (Twardowski, 2005). 
In reference to the group of children with disabilities or disabilities at- risk we can meet the concept of preventive interventions. The aim of the intervention specified by Beckwith (2000 p. 439 for: Firkowska-Mankiewicz, 2004) is the increase of the possibilities for the child's development in childhood and adolescence to proceed normally and to reduce the risk of the future problems in development.

One should distinguish the three levels of prevention programs:

1. The level of primary prevention- this is related to the provision of services aimed at reducing or preventing the disease or disability in reference to the whole society.

2. Secondary prevention - the services provided refer to the so called highrisk group and their aim is also to reduce or to prevent the occurrence of the disease.

3. The third level of prevention includes services provided to people who are sick or affected by the disorder. They aim at the limitation of the consequences of these disorders (Jourdan-Jonescu, 2003, for: Firkowska-Mankiewicz, 2004).

Today, the concept of prevention is associated with three basic levels:

1. Undertaking the action before issues arise. The educational activities are aimed at the elimination of destructive factors, modification of the educational environment, teaching new skills of dealing with the requirements of life.

2. Undertaking the activities in the initial phase of difficulties directed at solving the existing problem and reducing the risk of occurrence of more serious deeper disorders.

3. Undertaking the activities after the crisis is solved and concentration on the individuals who participated in the intervention programme. (Zabłocki, Brejnak).

On the grounds of the special pedagogy there three stages of prevention are determined (Kossakowski 2000):

- primary: the activities concerning the elimination of a pathogen factor,

- secondary: a pathogen factor occurred, and the activities are undertaken towards the prevention of occurrence of deviations from the standards,

- tertiary: the activities aiming at reduction of the consequences of deviations from the standards( Kosakowski, 2000).

Widely spread term , the early intervention"means multidisciplinary services offered to the children in order to improve their health condition and comfort ( welfare), to draw attention to their competence, to reduce to minimum their developmental delays, to improve existing or emerging disability, to prevent deterioration in the functioning as well as to help the family in adjustment to the existing situation (Shonkoff, Meisels, 2000, s.17,18; za: Firkowska-Mankiewicz, 2004).

Early intervention to reduce a risk the occurrence of the developmental delays of the child as well as to decrease the secondary results related to the deterioration of the child's disability, to support the whole of the family of child threatened by disability or disabled. 
It should be emphasised that the therapist in the scope of early intervention becomes the parents' companion in the process of struggling with problems arising from the child's disability for many years.( Cieszyńska, Korendo 1988).

Work at the home area is a very difficult and important aspect of the early intervention therapist' $s$ job especially when there is a threat for the diagnosis of the following life dysfunctions:

- threat of mental retardation of different origin,

- cerebral palsy or other damage of the central nervous system,

- behavioural disorders,

- disorders after chronic diseases of bacterial and viral character (conditions after cerebrospinal meningitis, encephalitis),

- sensory disturbances (vision, hearing, impaired feedback),

- extensive developmental disorders (autism and others).

Early intervention is inextricably linked to the term of functional diagnosis in which the assessment of the child's development should have the features of a diagnosis of the functional skills: large and small motor skills, imitation, perception, communication skills as well as cognitive and social. Functional diagnosis is the starting point for constructing a multi-profile rehabilitation program.

Therapeutic program should include a set of well-determined tasks and objectives as well as to include the procedure for their execution. An important component of early intervention treatment programs is to assess your child's progress, evaluation program and sometimes the judgement on the need re-diagnosis.

The most popular methods :

- sensory integrations,

- Development of the Theory of Mind Baron-Cohen,

- Developmental Movement W.Sherborne,

- Program Activity Ch.Knill,

- Good Start-M.Bogdanowicz,

- Alternative Communications methods; Bliss,

- behavioral methods of education.

\section{Government Pilot Program}

One of the best prepared, innovative programs for the development of early intervention was WWKSC [Early, multi-specialist, comprehensive, coordinated and continuous assistance] government program implemented in the years 2005-2007 which means as an early, multi-specialist, comprehensive, coordinated and continuous help to the children threatened by disability and disabled and their families.

According to the creators of the program the following premises support the earliest possible diagnosis of the risks and problems as well as undertaking rehabilitation, therapy and support of the children's development: 
- extremely high plasticity of the central nervous system during early development and the possibility of correction of the disturbed functions and compensation of the deficits,

- the possibility to inhibit the development of many disorders of a progressive course, and sometimes even to stop the adverse changes completely,

- greater susceptibility of young children to revalidation process and as a result faster improvement progress,

- easy generalization of the worked our skills and habits by the children,

- accumulation of a number of disorders with age and complication in therapy and education of elder children,

- parents of young children are usually more involved in working with specialists and their own participation in the child's therapy (www.menis.gov.pl).

It was also emphasized within the program objectives that in the event of a threat of disorder in child's development an essential condition for positive effects is to undertake diagnostic and therapeutic and rehabilitation action as soon as possible, even immediately after birth. The creators of the programme also stressed the importance of the following problem areas:

- a child is still diagnosed too late in Poland, i.e. even at the age of 2-5 years, although the symptoms of disorders are often visible earlier and they are indicated by the concerned parents,

- the physicians who examine the children in the first period of their lives, inadequately respond to alarming symptoms and for example do not refer the child to the specialist for additional examinations,

- access to specialist care is difficult (the physicians are grouped in large centres or clinics, there are too few of them) as well as information for parents is not sufficient. It is worth emphasizing that in the event of the significant number of children only with minor disorders and developmental delays or inharmonious development early assistance can bring to a complete equalization of the problems. Children whose development is seriously disordered due to early assistance have a chance to involve all their positive potential. These measures also prevent the deterioration of their state and perpetuation of the negative results of the children's disability.

A significant issue for the efficient functioning of early intervention is the fact that departmental and organizational divisions existing in Poland make the partial assistance conducted separately or not conducted at all.

There early medical, rehabilitation and therapeutic intervention exists within the Ministry of Health, which refers to the areas of health care for the child and family. Ministry of Education is an early psychological and pedagogical support of the child's development and upbringing as well as psychological and educational assistance for the child and his/ her family. Within the Ministry of Social Affairs, the family can obtain appropriate benefits if they do not achieve a determined threshold of income and apply for to financial assistance The situation is additionally complicated by the fact that the decisions or opinions 
on the need of early intervention in the institutions funded by the National Health Fund, early support of development in the department of education and the child's disability for the purposes of benefits as well allowances have been executed according to different criteria, procedures and different bodies. Under the new program, multidisciplinary, comprehensive and coordinated assistance of the interministerial character was recommended.

As it has been already emphasised in the programme the first years of the child's life are the most important for his/her development of independence, maturity to study at school as well as his/her efficiency and efficiency and functioning of the adult in the future. For the children who were diagnosed to be threatened by disability or with disability there is a need of permanent, insightful tracing of the health condition and psychomotor development as well as performance of the therapy programme dependent on the health and development needs of the child by the permanent team of the specialists.

- The objectives of the programme were determined as:

- preventing the occurrence and deterioration of disability,

- the assistance to the child in full use of his/ her developmental potential,

- identification of fortes of manifold and deeply disabled children,

- assistance to the child in building permanent relations with the closest people,

- setting off and reinforcing of social and cognitive activity and communication of the child (including development of speech and language),

- assistance to the child in gradual achievement of greater autonomy.

- systematic efforts to improve the child's quality of life, to provide him/her with full joy, tension-free childhood, in spite of the occurred disability or developmental disorders,

- preparation of the child with physical, sensory, intellectual and mental disability to use the education and existence in a group,

- preparation of the child for independent use of the activities organized in educational institutions and educational services for all the children.

- according to program guidelines early assistance concern the children aged between 0 and 7 years of age to complete, who are:

a) children from the group of high pregnancy-natal high-risk, threatened with abnormal development,

b) psychomotorically retarded or mentally handicapped and / or disabled and coupled in the course of various disease classifications:

- congenital malformations of the nervous system (such as meningo-core hernia, microcephaly, congenital hydrocephalus),

- genetic disease syndromes including chromosomal aberrations (eg, Down syndrome),

- metabolic diseases of the nervous system,

- disease classifications in which the main symptom is mental disability or mental disability without established etiology, 
- disease classifications where the main symptoms are persistent locomotor dysfunction (.i.e. children's cerebral palsy, myopathies, neuromuscular atrophy, the consequences of trauma and inflammatory CNS),

- microdisorder complexes of brain functions of severe course,

- sensory integration disorder of severe disease course,

- epileptic syndromes,

- other disease classifications affecting the abnormal psychomotor development,

- multiple disabilities i.e mental retardation with coupled disabilities of hearing, vision, movement, and the other ones,

- with abnormal psychomotor development without established etiology,

- with complex developmental disorders (autism, Asperger syndrome, Rett syndrome),

- blind or partially sighted,

- deaf or hard of hearing,

- of various disabilities.

In the event of children who have delayed execution of the compulsory school duty the care can be carried out continuously up to 10 years of age.

According to the creators of the government program WWKSC performance of the assistance program depending on a child, brings a variety of results:

- allows for complete elimination of disability and continuation of normal development,

- prevents to preserve disability and enables to continue further, normal development with only small extent of therapeutical aid,

- allows to involve the potential reserves of the development process of children whose disability is irreversible which improves their general health as well as personal and social functioning. They will be better prepared to start school, perhaps even integration in the future, due to early support vocational training opportunities will be available to them as well as jobs and more independent living in the integration,

- it allows to identify the fortes of the children manifold and profoundly disabled, building satisfactory contact and activity on them and prevent deepening the deficits that inhbit the development, reduce care possibilities and dramatically decrease quality of life of those children.

According to the creators of the programme children covered by WWKSC in the form of early intervention and early psychopedagogic development support earlier gain efficiency in the scope of self-service, or at least reach maturity of the digestive and excretory system, they become more physically efficient, more matured cognitively and emotionally, ready to gain separation from their parents and to learn outside home, at school or facility. Better, more harmonious development of the child during the first years of his/her life makes that later studying at school and peer contacts can achieve higher level and bring better results, and the need for costly and less efficient individual teaching at home is limitedChildren who 
are permanently disabled due to early intervention may obtain the necessary basis for the development of the personality traits particularly important in a balanced functioning as an independent adult.

Early multi-specialised, comprehensive and coordinated aid is to be a simultaneous medical, rehabilitation and therapeutic treatment (early intervention) and rehabilitation and educational activities(to support early development), which are covered by one program. Jointly developed and implemented by a team of professionals consisting of the physicians of various specializations psychologist, speech therapist, physiotherapist, occupational therapist and the therapists of other specializations. The innovation of WWKSC program was to highlight the role of teamwork as well as the tasks of specialists were to be focused on the following objectives:

- establishing of multidisciplinary diagnosis: medical, psychological and speech therapy as well as the assessment of the child's physical sphere,

- development and implementation of a detailed, multidisciplinary and comprehensive program in the mental, physical, social and emotional sphere of the child,

- monitoring of the child's development by updating the diagnosis and treatment programs to the changing developmental needs of the child,

- development and implementation of the educational and therapeutic programs for families.

Presented above programs aims were introduced and conducted by 55 institutions cross whole country between 2005-2007. After this period the results were presented as a final report. This report was controversial and not accepted by some specialists who were involved in this program. The most important results coming from the project contain following conclusions:

- 9159 children have possibility to benefit from complete rehabilitation programs provided by one centre.

- It can be assumed that children will succeed in their education and as adults they will be economical and social independent. There fore these may prevent social isolation in the future.

- Therapy of handicapped children was multi-specialist, comprehensive, coordinated and effected increase of II and social skills and global health improve.

- Small children involved in this program are prepared further education and social skills in integration schools. The possibility of psychiatric health care for small children has been extended relatively to their needs and possibility of introduction of addicional aims for family support. Finally it help in increase of parents involved in therapeutic process.

- The number of children at ages from 0-3 years old threatened by disability and disabled who join the program have increased.

- The quality of therapeutic teams have increased, their works focused on therapy standard improvement, the general working standard has been created. 
- Due to the therapeutic program which was conducted by one team it has been observed that the relation between parents and personal improved.

- Therapeutic centers has established roles of cooperation with new born child centers and with older children.

- The cooperation between doctors, teachers and clerks have been improved what effected in increase of community of awareness of early intervention.

Major recommendations coming out from program:

- continuation of effort aimed at interresort and selfcoordinated system of early intervention and created possibilities for diminishing of interresort differences,

- continuation of coordination in following areas: health, social employment and education aimed at satisfy of needs of handicapped children,

- cojoined covering of expenses connected with medical early intervention, early psychological intervention and providing to the parents by :NFZ, government, PFRON,

- creation of awareness of needs of the child with a disability at- risk or a disability,

- continuation of actions aimed at popularization of knowledge of low regulation possibilities of early intervention,

- increase of social awareness in respect to the all participants in this program and making motivation of local government to design and conducting the therapy of handicapped children,

- leading to start to realization the education duty by disabled children together with their healthy peer.

\section{The Role of the Family in Supporting the Early Development}

Each family, also this one raising a disabled child, functions as a certain social system (Grochowska, 2000). As it is emphasized by Tomkiewicz (1975), having in the family a child with developmental disorder must result in a more or less profound changes in the mutual relations existing in this system. The occurrence of disorders in the development of a child is a strongly stressful factor for other family members. The logic premise of such approach to the issues of families with a disabled person is the requirement to optimize the entire family system (Kościelska, 1998).

It is worth emphasizing that more and more frequently in working with children with developmental disorders the advantages of the focused approach on family are appreciated ("family centred approach") (Pisula, 1998).

The appearance of a disabled child in the family causes problems which interfere with normal educational process. After having heard the diagnosis, the feelings of the parents revolve around such feelings as sadness, despair, anger, distrust, 
disbelief, sense of injustice and sometimes shame. Mental crisis experienced by the parents consists mostly of constant fear for the health and development of the child, the sense of loss associated with insufficient information, a sense of shame and lack of acceptance in the community, lack of understanding of child behaviours and inability to respond to them. (Konarska, 2003). Handling the diagnostic and therapeutic process in the event of early intervention is often not possible without the participation of the parents. Parents have an opportunity to observe the child's behaviours throughout 24 hours and in different situations. Frequently the closest person from the environment may notice something which cannot be seen or caused by the specialist in his/her office and which can be a very important diagnostic symptom.Early intervention in its assumption strongly emphasises the development of appropriate, bilateral relations between parents and professionals. K. Mrugalska (1999) presents a set of positive characteristics of the parents and professionals in the mutual contacts. In the model terms of this author', parents try to establish good contact with the child and improve their educational influence in cooperation with the specialists. They support the efforts of the child, creating conditions which stimulate the development; they see the most important skills suitable for the child's development included in its different spheres and do not focus exclusively on intellectual or physical one. They systematically seek to obtain specific advice and to clarify the doubts that concern them and the continuous improvement of their conduct with a child as well as to fulfil the recommendations and report the degree of advice efficiency, thus providing satisfaction to the qualified professionals. They continually deepen their psycho-pedagogical knowledge, including the contacts with other parents in the same situation.

The professionals inform parents about the issues related to the state of a child in a way that takes into account the feelings of the parents and their willingness to help him/her, treating the child with a disability as a person developing within his/her own rate and possibilities. They provide support to the family and help it see the positive characteristics of the child, his/her successes and accept their situation;they show their respect to parents and appreciation for their efforts. They continue to enhance their knowledge and analytical approach to the achieved clinical experience. The formation of these features in relation "parent - professional" guarantees good cooperation and understanding, which is the basis for the proper conduct of the rehabilitation of the disabled child (Tiggy-Winkle, 1999).

As Pisula pointed out (1998) this is known that determination of the level of stress accumulation, its type and intensity is not enough to be able to predict the impacts these burdens will have on the individual and the family. For those working with parents of the disabled, it is important to identify factors moderating stress levels so that they can actively protect the families from its excessive intensity. Autism is an example of the disease which causes a very strong disruption in the functioning of the entire family. In accordance with Randall and Parker 
(2001) autism in the family creates an extremely difficult situation, unknown in other disorders.

According to Bristol (1993, for: Pisula, 1998), there are several reasons why autism is a developmental disorder extremely stressful, and they include:

- ambiguity of the situation related to the normal appearance of an autistic child,

- profound degree of disorder,

- duration - due to the inability to cure autism,

- environmental influences.

The results show that parents (especially mothers of autistic children) often suffer from depression(Bristol, 1987; O’Moore, 1978 by: Pisula, 1998), which should be associated with the accumulation of stressful events and the frequent loss of self-development opportunities.

Research on anxiety and depression in parents of children with autism were also conducted by Ryde - Brandt $(1990,1991)$. It was found out that mothers of the children with autism presented higher levels of anxiety and depression than mothers of the children with motor disorders and children with Down syndrome. Olechnowicz (1983) emphasises the issue of the presence of the behaviours indicating the learned helplessness in the parents of children with autistic behaviours Parents of these children often have the belief that the efforts undertaken by them to not bring any results.

In 1979 Sullivan first introduced the concept of the burn-out syndrom in parents of children with autism. No adequate support system to the needs of the family, the emotional, financial and time pressure in which many parents of autistic children live are some of the reasons of this syndrome in people ho take care of their autistic children (Gałkowski, 1995). Research on the „burn - out” syndrome in parents of children with autism in Poland began over 15 year, ago a team conducted by Professor Gałkowski (1995). The subject of the studies was to characterize the intensity of the 15 factors specific to "the burn-out "syndrom. Analysis of the results proved greater severity of the presence of all fifteen factors in a group of the parents of the autistic children in relation to a group of parents of children with intellectual disabilities.

Research conducted by Gałkowski (1995) in France showed significantly greater severity of , burn out, syndrome among the Polish parents in relation to the parents of autistic children in France. Today, many public campaigns aimed at bringing public awareness of autism, professionals working in early intervention centres may extend their competence in diagnostic and therapeutic workshops and specialized courses, but the condition in which the families of children with autism in Poland remain is a matter of great concern. (Cf. Blaszczyk, 2008).

The creators of WWKSC program consider the support to the families of the children at risk for disability and disabled ones as a very important element for the success of early intervention process. The aim of the pilot for the parents was: 
- Psychological support in the event of experiencing a shock, a sense of loss, prolonged stress due to childbirth defined as a disabled one.

- The assistance to the parents to adapt to the conditions of life, resulting from the fact of raising a disabled child and to the competent organization of his/ her life.

- The assistance to create an environment beneficial in building an emotional relations between the parents and the child.

- Preparing the parents to participate in early intervention and support for child's development.

- Appropriate assistance to the parents in the home environment organization, adapted to the special needs of the child, taking into account the needs of healthy siblings.

- Assistance to the parents to achieve a sense of parental competence and satisfaction in the educational process.

- Assistance to the parents in creating the realistic expectations of child's development, in accordance with its capabilities and the stage at which he/she is, developing a sense of participation in a wider group of parents of the disabled children and proper the distance to their situation.

In practice, the presented model of comprehensive care for the child's family threatened with a disability or a disabled one still remains rare (see Błaszczyk, 2008). It is hoped that there is an intensive development of the field called the early intervention, in front of us which will allow children with disordered development and their families to achieve satisfactory results in therapy.

\section{Summary}

In clinical practice, we encounter more and more children, the sick and the disturbed in their development affected not only by one mental and somatic problem(por.Winczura, 2012). Increased incidence of developmental disorders observed in recent years I.e. within autism spectrum make the researchers the search for more effective treatments within the early intervention (McCandless, 2007). Early intervention is an interdisciplinary approach, which allows taking special care of the child and his/her family from the time of diagnosis of the first alarming symptoms of the disorder. To undertake the action in order to stimulate the child at an early stage of development has a direct impact on his/her achievement of greater autonomy, independence and quality of life in adulthood.

The benefits of functioning early intervention institutions are long-term ones and include the functioning of the whole of the society. Facing these data how to explain the fact that in practice the subject of multidisciplinary early development support is so much neglected in Poland. 


\section{References}

Błaszczyk S. (2008). Funkcjonowanie psychospołeczne rodziców i rodzeństwa dziecka autystycznego.Problemy Opiekuńczo-Wychowawcze,3/2008, p.40-44.

Błaszczyk S., Kałużna- Czaplińska J. (2012). The level of arabinitol in autistic children after probiotic therapy. Nutrition.p. 124-126. Elsevier.

Cieszyńska J, Korendo M. (2008). Wczesna interwencja terapeutyczna.Stymulacja rozwoju dziecka. Wydawnictwo Edukacyjne.

Cytowska B. (2008). Idea wczesnej interwencji i wspomagania rozwoju małego dziecka. [In:] Cytowska B., Winczura B. (Eds.). Wczesna interwencja i wspomaganie rozwoju małego dziecka. Wydawnictwo Impuls.

Firkowska-Mankiewicz A. (2004). Rola wczesnej interwencji. [In:] Materiały z Międzynarodowej konferencji Naukowo-Szkoleniowej ,Wielospecjalistyczna kompleksowa pomoc małemu dziecku z zaburzeniami rozwoju i jego rodzinie w ośrodku wczesnej interwencji”.

Gałkowski T. (1995). Dziecko autystyczne w środowisku rodzinnym i szkolnym. Warszawa: WSZiP.

Grochowska J. (2000). Życie w cieniu autyzmu. Rodzeństwo dzieci autystycznych. Dziecko Autystyczne, v. 8, 1, 35-57.

Konarska J. (2003). Niepełnosprawność dziecka jako sytuacja kryzysowa w rodzinie, W:KubackaJasiecka D, Mudyń K. (Ed.). Kryzys,interwencja i pomoc psychologiczna.Nowe ujęcia i możliwości. Toruń:Wydawnictwo Adam Marszałek p. 28-42.

Kosakowski C. (2000). Niepetnosprawność ludzka [In:] Kosakowski C, Zaorska, (Ed.). Dziecko o specjalnych potrzebach edukacyjnych.. Toruń: Wydawnictwa Akapit.

Kościelska M. (1998). Trudne macierzyństwo. Warszawa: WSiP.

McCandless J.(2007). Dzieci z głodującymi mózgami. przewodnik terapii medycznych dla chorób ze spektrum autyzmu. Warszawa: Fraszka Edukacyjna.

Mrugalska K. (1999). Czy rodzice i profesjonaliści moga być sojusznikami. [In:] Olechnowicz H. (Ed.). U źródet rozwoju dziecka: o wspomaganiu rozwoju prawidłowego i zakłóconego. WSiP, p. 38-50.

Olechnowicz H. (1983). Wczesny autyzm dziecięcy. Symptomatogia, diagnostyka, etiologia i terapia. [In:] Czownicka E. (Ed.). Psychologiczne problemy wczesnego autyzmu dziecięcego. Warszawa: WSPS.

Pisula E. (1998). Psychologiczne problemy rodziców dzieci z zaburzeniami w rozwoju. Warszawa: Wydawnictwo Uniwersytetu Warszawskiego.

Piszczek M. (2007). Diagnoza i wspomaganie rozwoju dziecka. Wybrane zagadnienia. Warszawa: CMPPP.

Randall P., Parker J. (2001). Autyzm: jak pomóc rodzinie? Gdańsk: GWP.

Ryde-Brandt B. (1990). Anxiety and Demence strategies in mothers of children with different disabilities. British Journal of Medical Psychology, 63, p. 183 - 192.

Ryde-Brandt B. (1991). Defence strategies and anxiety in mothers of disabled children. European Journal of Personality, 5, p. 367-377.

Serafin T. (2005). Wczesne wspomaganie rozwoju dziecka od chwili wykrycia niepetnosprawności do podjęcia nauki w szkole. Poradnik dla organizatorów działań, dla terapeutów, oraz dla rodziców. Warszawa: MENiS.

Shaw W. (2002). Biological Treatments for Autism and PDD. Lenexa KS.

Tomkiewicz S. (1975). Więź rodziny z dzieckiem upośledzonym umysłowo [In:] Gałkowski T. (Ed.). Wybrane zagadnienia z defektologii, 3, p. 7-46, Warszawa.

Twardowski A. (2005). Wspomaganie rozwoju dziecka ze złożonymi zespołami zaburzeń. Poznań.

Zabłocki K., Brejnak W. (2009). Wczesna diagnoza i wspomaganie rozwoju dziecka z dysfunkcjami. Warszawa.

Winczura B. (2012). Dzieci z zaburzeniami łączonymi. Trudne ścieżki rozwoju. Wydawnictwo Impuls. 